\title{
Effect of some botanical materials on certain biological aspects of the house fly, Musca domestica $\mathrm{L}$.
}

\author{
Nabawy A. I. Elkattan, Khalafalla S. Ahmed, Saadya M. Elbermawy and Rabab \\ M. Abdel-Gawad \\ Biological and Geological Sciences Department, Faculty of Education, Ain Shams \\ University.
}

\begin{abstract}
The effects of Lantana camara (leaves), Pelargonium zonale (leaves), Cupressus macrocarpa (leaves), Cyperus rotundus (whole plant) and Acacia nilotica (seeds) powders on some biological aspects of house fly, M. domestica L. were tested. The effects of three lethal concentrations $\mathrm{LC}_{25}, \mathrm{LC}_{50}$ and $\mathrm{LC}_{75}$ on the larval duration, pupation percent, pupal weight, pupal duration, adult emergence percent, sex ratio, adult longevity, and fecundity were determined. The induced malformed larvae, pupae and adults were recorded and photographed. The powders of the five plants were found to have promising effects in controlling this insect.
\end{abstract}

Keywords: Musca domestica; Lantana camara; Pelargonium zonale; Cupressus macrocarpa; Cyperus rotundus; Acacia nilotica; Biological studies.

\section{Introduction}

The house fly, Musca domestica L., is a serious pest to livestock and a public health pest that acts as a transmitter of many human and animal diseases (Emerson et al., 1999; Douglass and Jesse, 2002; Mian et al., 2002).

House fly has been successfully controlled by the application of various insecticides, but reports of insecticide resistance in this insect have been amply found (Kaufman et al., 2001; Shono and Scott, 2004). For this reason, alternative house fly control strategies, including the use of botanical insecticides have been studied (WangJian et al., 2005; Ghoneim et al., 2007; Pavela, 2008; Sripongpun, 2008; Tarelli et al., 2009).

Plants and plant products are recently considered alternatives to conventional insect-control agents as they constitute a rich source of bioactive chemicals, against number of species including specific target insects, and are often biodegradable to non-toxic products (Hashem and Youssef, 1991).
The successful use of plant products in the control of certain insect species depends on contained substances that inhibit the developmental process of those insects (Kristensen and Jespersen, 2003). From these points of view, the aim of this research was to study the effect of some plant materials on the house fly population and the possibility of using these materials as larvicides for controlling the insect by treating insect's breeding places.

\section{Material and methods}

\section{Insect rearing}

Musca domestica L. colony was obtained from the Medical Insect Research Center, Dokki, Giza. The adults were allowed free access to sugar and cotton pads soaked in milk powder dissolved in water $(10 \%$ w/v). Larvae were reared according to the method described by Pavela (2008) and Huang et al. (2008) on a mixture of sterilized bran (38 g), milk powder (2 g) and water $(60 \mathrm{ml})$, and maintained at $27 \pm 2^{\circ} \mathrm{C}$ and $70 \pm 5 \%$ relative humidity (RH). 


\section{Tested plants}

The sublethal concentrations $\left(\mathrm{LC}_{25}, \mathrm{LC}_{50}\right.$ and $\mathrm{LC}_{75}$ ) of leave's powder of L. camara, $P$. zonale and C. macrocarpa; whole plant powder of $C$. rotundus, and seed's powder of $A$. nilotica were determined in previous work (Elbermawy et al., 2011).

\section{Biological studies}

The experiments were carried out on the $2^{\text {nd }}$ instar larvae (3- days old). The larval media were treated with $\mathrm{LC}_{25}, \mathrm{LC}_{50}$ and $\mathrm{LC}_{75}$ of each tested plant. The treated media was divided in $250 \mathrm{ml}$ beakers each received $50 \mathrm{~g}$ of media. Normal larvae were transferred from rearing media to each beaker (25 larvae). Control experiments were done as above but without any treatment. This procedure was repeated 4 times. All tests were carried out at laboratory conditions mentioned above.

Larvae were examined daily to estimate larval duration which was calculated as the intervals between the commencement of $1^{\text {st }}$ instar larvae and that of pupation. It was calculated for each larva and then the mean value was taken. Mortality was recorded daily until pupation.

The resultant pupae were counted and weighed to determine the percent of pupation and the mean pupal weight. Observations were carried out daily to record pupal duration. The reduction in pupal weight and adult emergence was calculated according to Khazanie (1979). Percentage of total pupae developed to adults was estimated according to Sripongpun (2008) and the emergence of successfully metamorphosed adults was estimated in percentage according to Jimenez Peydro et al. (1995).

The emerged males and females adults were transferred daily to oviposition cages, containing sugar and cotton pads served for feeding and oviposition, the cotton pads were renewed daily. Mean longevity for each sex was calculated according to Fletcher et al. (1990).The total number of eggs was recorded and the number of eggs laid per female (fecundity) was calculated. Percent fecundity was determined according to Crystal (1964). The oviposition deterrent index was calculated according to Lundgren (1975). The eggs were moved to Petri dishes containing filter paper moisten by water. Control and treated eggs were incubated under the same laboratory conditions. One day later, the emerged larvae were counted and the percent of egg hatch was determined. The sterility was calculated according to Toppozada et al. (1966). Any morphogenetic abnormalities that might occur in all developmental stages were recorded and photographed.

\section{Results}

\section{Larval duration:}

Results in Table 1 revealed that the larval duration of the control larvae of $M$. domestica was $6.31 \pm 0.98$ days. A significant prolongation in the larval duration of the treated larvae was observed in larvae treated with $\mathrm{LC}_{25}$ of $C$. macrocarpa. Also, a highly significant prolongation in the larval duration was observed in larvae treated with $\mathrm{LC}_{25}, \mathrm{LC}_{50}$ and $\mathrm{LC}_{75}$ of $L$. camara, $P$. zonale and $C$. rotundus and $\mathrm{LC}_{50}$ of $C$. macrocarpa. On the contrary, $\mathrm{LC}_{50}$ of A. nilotica caused a highly significant reduction in the average larval period compared to controls. On the other hand, there was insignificant effect on the larval duration after treatment with $\mathrm{LC}_{25}$ of $A$. nilotica and $\mathrm{LC}_{75}$ of $C$. macrocarpa as compared with controls.

\section{Pupation percent, pupal weight and pupal duration:}

Results shown in Table 2 revealed that a significant reduction of pupation percent was induced by using $\mathrm{LC}_{25}$ of $P$. zonale and $\mathrm{LC}_{50}$ of $L$. camara. Also, a highly significant decrease in the pupation percent was observed in treatments with $\mathrm{LC}_{75}$ of $L$. camara, $\mathrm{LC}_{50}$ and $\mathrm{LC}_{75}$ of $P$. zonale, all LC's of $C$. rotundus and $C$. macrocarpa and A. nilotica. The percent pupation was decreased as the concentration of plant powder increased.

Larvae of $M$. domestica raised on tested plant materials diets recorded a highly significant lower pupal average weight 
Nabawy Elkattan... et al

and the average pupal weights dropped with increased concentration and the effect of plant materials is rated as follows: $P$. zonale $>C$. rotundus $>$ A. nilotica $>C$. macrocarpa $>$ L. camara. Also, a highly significant prolongation in the pupal duration was observed in all tested concentration of all plant materials (Table 2).

Table 1: Effect of the tested plant materials on the larval duration of $M$. domestica treated as $2^{\text {nd }}$ larval instar, at $27^{\circ} \mathrm{C}$.

\begin{tabular}{|c|c|c|c|c|c|c|c|}
\hline \multirow{2}{*}{\multicolumn{2}{|c|}{ Treatment }} & \multicolumn{3}{|c|}{ Larval duration (days) } & \multirow{2}{*}{$\begin{array}{c}\text { Change } \\
\%\end{array}$} & \multicolumn{2}{|c|}{$t$-Test } \\
\hline & & Min. & Max. & Mean \pm SD & & $P$-value & $\begin{array}{c}\text { Significance } \\
\text { level }^{(1)}\end{array}$ \\
\hline \multicolumn{2}{|c|}{ Control } & 5 & 8 & $6.31 \pm 0.98$ & - & - & - \\
\hline \multirow{3}{*}{ 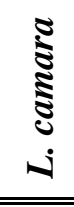 } & $\mathrm{LC}_{25}$ & 5 & 10 & $7.41 \pm 1.30$ & 17.37 & 0.000 & $* *$ \\
\hline & $\mathrm{LC}_{50}$ & 6 & 10 & $7.47 \pm 1.48$ & 18.44 & 0.000 & $* *$ \\
\hline & $\mathrm{LC}_{75}$ & 6 & 9 & $7.09 \pm 1.02$ & 12.43 & 0.000 & $* *$ \\
\hline \multirow{3}{*}{ 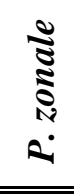 } & $\mathrm{LC}_{25}$ & 7 & 10 & $8.41 \pm 0.79$ & 33.34 & 0.000 & $* *$ \\
\hline & $\mathrm{LC}_{50}$ & 8 & 10 & $9.44 \pm 0.62$ & 49.69 & 0.000 & $* *$ \\
\hline & $\mathrm{LC}_{75}$ & 8 & 10 & $9.22 \pm 0.55$ & 46.20 & 0.000 & $* *$ \\
\hline \multirow{3}{*}{ 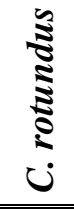 } & $\mathrm{LC}_{25}$ & 6 & 10 & $7.45 \pm 1.14$ & 18.09 & 0.000 & $* *$ \\
\hline & $\mathrm{LC}_{50}$ & 6 & 9 & $7.11 \pm 0.87$ & 12.65 & 0.000 & $* *$ \\
\hline & $\mathrm{LC}_{75}$ & 6 & 8 & $7.05 \pm 0.62$ & 11.80 & 0.000 & $* *$ \\
\hline \multirow{3}{*}{ 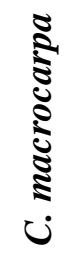 } & $\mathrm{LC}_{25}$ & 5 & 8 & $6.67 \pm 0.81$ & 5.66 & 0.016 & $*$ \\
\hline & $\mathrm{LC}_{50}$ & 6 & 8 & $6.78 \pm 0.59$ & 7.46 & 0.001 & $* *$ \\
\hline & $\mathrm{LC}_{75}$ & 6 & 8 & $6.57 \pm 0.73$ & 4.11 & 0.099 & $\mathrm{~ns}$ \\
\hline \multirow{2}{*}{ 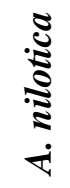 } & $\mathrm{LC}_{25}$ & 6 & 8 & $6.10 \pm 0.38$ & -3.32 & 0.074 & $\mathrm{~ns}$ \\
\hline & $\mathrm{LC}_{50}$ & 5 & 7 & $5.07 \pm 0.30$ & -19.69 & 0.000 & $* *$ \\
\hline
\end{tabular}

(1) Significance level: n.s. (insignificant), * (significant), ** (highly significant) as compared with control. 
Effect of some....

Table 2: Effect of the tested plant materials on pupation percent, pupal weight and pupal duration of $M$. domestica treated as $2^{\text {nd }}$ larval instar, at $27^{\circ} \mathrm{C}$.

\begin{tabular}{|c|c|c|c|c|c|c|c|}
\hline \multicolumn{2}{|c|}{ Treatment } & $\begin{array}{c}\% \\
\text { Pupation }\end{array}$ & $\begin{array}{c}\% \\
\text { Inhibition } \\
\text { in } \\
\text { pupation }\end{array}$ & $\begin{array}{c}\text { Pupal } \\
\text { weight }(\mathbf{m g}) \\
(\text { Mean } \pm \text { SD) }\end{array}$ & $\begin{array}{c}\% \\
\text { Reduction } \\
\text { in pupal } \\
\text { weight }\end{array}$ & $\begin{array}{c}\text { Pupal } \\
\text { duration } \\
\text { (days) } \\
(\text { Mean } \pm \text { SD) }\end{array}$ & $\begin{array}{c}\% \\
\text { Change } \\
\text { in pupal } \\
\text { duration }\end{array}$ \\
\hline \multicolumn{2}{|c|}{ Control } & $97 \pm 3.83$ & 0.00 & $19.66 \pm 2.34$ & & $4.51 \pm 1.14$ & \\
\hline \multirow{3}{*}{ 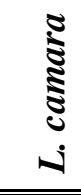 } & $\mathrm{LC}_{25}$ & $79 \pm 16.77^{\text {ns }}$ & 15.56 & $18.53 \pm 5.70^{* *}$ & 5.74 & $7.08 \pm 1.66^{* *}$ & 57.23 \\
\hline & $\mathrm{LC}_{50}$ & $74 \pm 12.44^{*}$ & 20.71 & $18.19 \pm 4.64^{* *}$ & 7.48 & $7.50 \pm 1.65^{* *}$ & 66.48 \\
\hline & $\mathrm{LC}_{75}$ & $64 \pm 5.66^{* *}$ & 31.02 & $17.30 \pm 3.84^{* *}$ & 12.02 & $7.08 \pm 1.53^{* *}$ & 57.19 \\
\hline \multirow{3}{*}{ 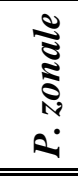 } & $\mathrm{LC}_{25}$ & $80 \pm 9.80^{*}$ & 14.53 & $9.98 \pm 3.65^{* *}$ & 49.26 & $6.49 \pm 1.30^{* *}$ & 44.13 \\
\hline & $\mathrm{LC}_{50}$ & $63 \pm 9.45^{* *}$ & 32.05 & $9.51 \pm 2.83^{* *}$ & 51.64 & $6.93 \pm 1.67^{* *}$ & 53.73 \\
\hline & $\mathrm{LC}_{75}$ & $49 \pm 8.25^{* *}$ & 46.48 & $7.51 \pm 2.00^{* * *}$ & 61.80 & $6.40 \pm 1.68^{* *}$ & 42.06 \\
\hline \multirow{3}{*}{ 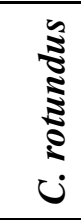 } & $\mathrm{LC}_{25}$ & $71 \pm 6.83^{* * *}$ & 23.80 & $10.90 \pm 2.49^{* *}$ & 44.55 & $5.87 \pm 1.20^{* *}$ & 30.37 \\
\hline & $\mathrm{LC}_{50}$ & $65 \pm 3.83^{* *}$ & 29.99 & $9.91 \pm 2.75^{* *}$ & 49.60 & $6.12 \pm 1.25^{* *}$ & 35.86 \\
\hline & $\mathrm{LC}_{75}$ & $37 \pm 2.00^{* *}$ & 58.86 & $8.38 \pm 1.74^{* *}$ & 57.38 & $6.61 \pm 1.72^{* *}$ & 46.79 \\
\hline \multirow{3}{*}{ 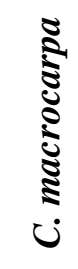 } & $\mathrm{LC}_{25}$ & $66 \pm 6.93^{* *}$ & 28.96 & $16.59 \pm 3.38^{* *}$ & 15.61 & $5.91 \pm 1.21^{* *}$ & 31.16 \\
\hline & $\mathrm{LC}_{50}$ & $59 \pm 6.83^{* *}$ & 36.18 & $14.61 \pm 3.27^{* *}$ & 25.69 & $6.13 \pm 1.33^{* *}$ & 36.11 \\
\hline & $\mathrm{LC}_{75}$ & $51 \pm 12.38^{* *}$ & 44.42 & $11.82 \pm 3.31^{* * *}$ & 39.86 & $5.94 \pm 1.45^{* *}$ & 31.95 \\
\hline \multirow{2}{*}{ 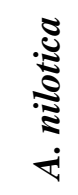 } & $\mathrm{LC}_{25}$ & $80 \pm 6.53^{* *}$ & 14.53 & $12.96 \pm 3.51^{* *}$ & 34.07 & $5.34 \pm 1.00^{* *}$ & 18.59 \\
\hline & $\mathrm{LC}_{50}$ & $75 \pm 5.03^{* *}$ & 19.68 & $10.30 \pm 2.69^{* *}$ & 47.60 & $5.95 \pm 1.33^{* *}$ & 32.07 \\
\hline
\end{tabular}

(1) Significance level: n.s. (insignificant), * (significant), ** (highly significant) as compared with control.

Percent adult emergence and adult longevity:

Results shown in Table 3, revealed a reduction in the percent of total pupae developed to adults. All the tested plant powders induced reduction in the percent of adult emerged from treated larvae. Changes in the sex ratios of emerged adults tended towards favoring males. The longevity of adults in both male and female flies was highly significantly decreased in all treatments comparing with the control.

\section{Reproductive potential:}

The treatment of $M$. domestica larvae with $\mathrm{LC}_{25}$ of $L$. camara caused a significant decrease in the number of eggs deposited per resulting female. Also, all LC's of $P$. zonale, $C$. rotundus, $A$. nilotica and $C$. macrocarpa, $\mathrm{LC}_{50}$ and $\mathrm{LC}_{75}$ of $L$. camara caused a highly significant decrease in fecundity of adult females. The tested plant powders showed a highly significant decrease in the egg hatching percent (Table 4). 
Nabawy Elkattan... et al

Table 3: Effect of the tested plant materials on the adult emergence percent, sex ratio and adult longevity of $M$. domestica treated as $2^{\text {nd }}$ larval instar, at $27^{\circ} \mathrm{C}$.

\begin{tabular}{|c|c|c|c|c|c|c|c|c|}
\hline \multirow{2}{*}{\multicolumn{2}{|c|}{ Treatment }} & \multirow{2}{*}{$\begin{array}{c}\% \text { of total } \\
\text { pupae } \\
\text { developed } \\
\text { to adults }\end{array}$} & \multirow{2}{*}{$\begin{array}{l}\text { \% Adult } \\
\text { emergence }\end{array}$} & \multirow{2}{*}{$\begin{array}{c}\% \\
\text { Inhibition } \\
\text { in adult } \\
\text { emergence }\end{array}$} & \multicolumn{2}{|c|}{ Sex ratio } & \multicolumn{2}{|c|}{$\begin{array}{l}\text { Adults longevity (days) } \\
\quad(\text { Mean } \pm \text { SD) }\end{array}$} \\
\hline & & & & & $0^{\pi}$ & q & $\hat{0}$ & 우 \\
\hline \multicolumn{2}{|c|}{ Control } & 100.00 & 97 & 0.00 & 49.48 & 50.52 & $16.52 \pm 1.15$ & $18.10 \pm 1.31$ \\
\hline \multirow{3}{*}{ 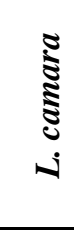 } & $\mathrm{LC}_{25}$ & 86.08 & 68 & 29.90 & 50.00 & 50.00 & $11.44 \pm 0.93^{* *}$ & $13.65 \pm 1.54^{* *}$ \\
\hline & $\mathrm{LC}_{50}$ & 62.16 & 46 & 52.58 & 54.35 & 45.65 & $8.32 \pm 1.65^{* *}$ & $10.90 \pm 1.97^{* *}$ \\
\hline & $\mathrm{LC}_{75}$ & 40.63 & 26 & 73.20 & 57.69 & 42.31 & $7.13 \pm 0.92^{* *}$ & $8.45 \pm 1.44^{* *}$ \\
\hline \multirow{3}{*}{ 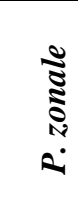 } & $\mathrm{LC}_{25}$ & 83.75 & 68 & 30.93 & 59.70 & 40.30 & $9.23 \pm 1.62^{* *}$ & $9.63 \pm 1.39^{* *}$ \\
\hline & $\mathrm{LC}_{50}$ & 85.71 & 50 & 44.33 & 46.30 & 53.70 & $8.12 \pm 0.73^{* *}$ & $9.66 \pm 1.70^{* *}$ \\
\hline & $\mathrm{LC}_{75}$ & 53.06 & 27 & 73.20 & 57.69 & 42.31 & $7.87 \pm 0.35^{* *}$ & $8.55 \pm 1.04^{* * *}$ \\
\hline \multirow{3}{*}{ ن } & $\mathrm{LC}_{25}$ & 95.77 & 68 & 29.90 & 54.41 & 45.59 & $6.67 \pm 0.84^{* *}$ & $8.03 \pm 0.80^{* *}$ \\
\hline & $\mathrm{LC}_{50}$ & 76.92 & 50 & 48.45 & 52.00 & 48.00 & $6.46 \pm 1.33^{* *}$ & $8.00 \pm 0.98^{* *}$ \\
\hline & $\mathrm{LC}_{75}$ & 72.97 & 27 & 72.16 & 51.85 & 48.15 & $5.07 \pm 0.92^{* *}$ & $6.62 \pm 0.51^{* *}$ \\
\hline \multirow{3}{*}{ 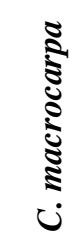 } & $\mathrm{LC}_{25}$ & 100.00 & 66 & 31.96 & 48.48 & 51.52 & $11.06 \pm 1.63^{* *}$ & $12.65 \pm 1.12^{* *}$ \\
\hline & $\mathrm{LC}_{50}$ & 86.44 & 51 & 47.42 & 58.82 & 41.18 & $10.63 \pm 1.10^{* *}$ & $11.19 \pm 0.87^{\text {** }}$ \\
\hline & $\mathrm{LC}_{75}$ & 54.90 & 28 & 71.13 & 60.71 & 39.29 & $7.29 \pm 0.99^{* *}$ & $8.18 \pm 0.87^{* * *}$ \\
\hline \multirow{2}{*}{ 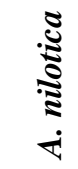 } & $\mathrm{LC}_{25}$ & 87.50 & 70 & 27.84 & 65.71 & 34.29 & $7.61 \pm 1.34^{* *}$ & $8.25 \pm 0.85^{* *}$ \\
\hline & $\mathrm{LC}_{50}$ & 70.67 & 53 & 45.36 & 66.04 & 33.96 & $6.37 \pm 0.81^{* *}$ & $8.06 \pm 0.87^{* *}$ \\
\hline
\end{tabular}

(1) Significance level: n.s. (insignificant), * (significant), ** (highly significant) as compared with control. 
Effect of some....

Table 4: Effect of the tested plant materials on Fecundity, Fecundity percent, \% ODI, Hatchability and Sterility percent of $M$. domestica treated as $2^{\text {nd }}$ larval instar, at $27^{\circ} \mathrm{C}$.

\begin{tabular}{|c|c|c|c|c|c|c|}
\hline \multicolumn{2}{|c|}{ Treatment } & $\begin{array}{c}\text { Fecundity } \\
\text { (no. } \\
\text { eggs/female) }\end{array}$ & $\begin{array}{c}\% \\
\text { Fecundity }\end{array}$ & $\%$ ODI & $\begin{array}{l}\text { Egg hatchability } \\
\text { (\% egg hatching) }\end{array}$ & $\%$ Sterility \\
\hline \multicolumn{2}{|c|}{ Control } & $191.35 \pm 18.55$ & 100.00 & 0.00 & $95.69 \pm 0.47$ & 0.00 \\
\hline \multirow{3}{*}{ 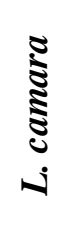 } & $\mathrm{LC}_{25}$ & $164.53 \pm 18.28^{*}$ & 85.99 & 7.53 & $89.64 \pm 2.14^{* *}$ & 19.44 \\
\hline & $\mathrm{LC}_{50}$ & $88.81 \pm 11.96^{* *}$ & 46.41 & 36.60 & $89.29 \pm 3.93^{* *}$ & 56.69 \\
\hline & $\mathrm{LC}_{75}$ & $50.04 \pm 6.45^{* *}$ & 26.15 & 58.54 & $75.77 \pm 5.89^{* *}$ & 79.29 \\
\hline \multirow{3}{*}{ 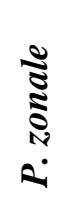 } & $\mathrm{LC}_{25}$ & $133.36 \pm 14.56^{* *}$ & 69.70 & 17.86 & $84.69 \pm 4.78^{* *}$ & 38.31 \\
\hline & $\mathrm{LC}_{50}$ & $131.13 \pm 19.09^{* *}$ & 68.53 & 18.67 & $82.36 \pm 3.33^{* *}$ & 41.01 \\
\hline & $\mathrm{LC}_{75}$ & $63.58 \pm 7.36^{* *}$ & 33.22 & 50.12 & $67.26 \pm 5.0^{* *}$ & 76.64 \\
\hline \multirow{3}{*}{ 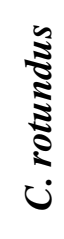 } & $\mathrm{LC}_{25}$ & $52.37 \pm 6.49^{* *}$ & 27.37 & 57.02 & $84.23 \pm 5.09^{* *}$ & 75.91 \\
\hline & $\mathrm{LC}_{50}$ & $50.44 \pm 6.60^{* *}$ & 26.36 & 58.28 & $81.46 \pm 2.41^{* *}$ & 77.56 \\
\hline & $\mathrm{LC}_{75}$ & $25.03 \pm 3.10^{* *}$ & 13.08 & 76.87 & $67.89 \pm 5.72^{* *}$ & 90.72 \\
\hline \multirow{3}{*}{ 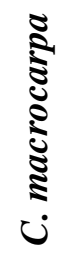 } & $\mathrm{LC}_{25}$ & $92.89 \pm 16.18^{* *}$ & 48.54 & 34.64 & $90.06 \pm 2.74^{* *}$ & 54.31 \\
\hline & $\mathrm{LC}_{50}$ & $50.76 \pm 4.52^{* *}$ & 26.53 & 58.07 & $79.21 \pm 5.09^{* *}$ & 78.04 \\
\hline & $\mathrm{LC}_{75}$ & $46.22 \pm 15.96^{* *}$ & 24.15 & 61.09 & $65.78 \pm 2.82^{* *}$ & 83.40 \\
\hline \multirow{2}{*}{ 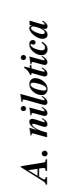 } & $\mathrm{LC}_{25}$ & $73.22 \pm 3.25^{* *}$ & 38.26 & 44.65 & $76.95 \pm 7.26^{* *}$ & 69.23 \\
\hline & $\mathrm{LC}_{50}$ & $29.76 \pm 7.48^{* *}$ & 15.56 & 73.08 & $76.81 \pm 8.68^{* *}$ & 87.51 \\
\hline
\end{tabular}

(1) Significance level: n.s. (insignificant), * (significant), ** (highly significant) as compared with control.

\section{Morphogenetic effects:}

In the present study, the application of all LC's of L. camara, P. zonale, C. rotundus, C. macrocarpa and A. nilotica against $M$. domestica induced different morphological abnormalities. Considerable number of larvae, pupae and adults showed obvious malformations after the treatment of $2^{\text {nd }}$ instar larvae with plant powders. Malformations include complete darkened larvae, curved larvae, irregular-shaped larvae, swelling larvae, larvae with patches of cuticle melanization, larval-pupal intermediates, compressed and shrinkage pupae, dry and darkened pupae, C-shaped pupa, peanut shaped pupa, and small sized pupae. Many adults could not emerge completely and remained concealed in the puparia. Other adults with defective wings, and deformed abdomen were also observed (Plates 1 - 3). 
Nabawy Elkattan... et al

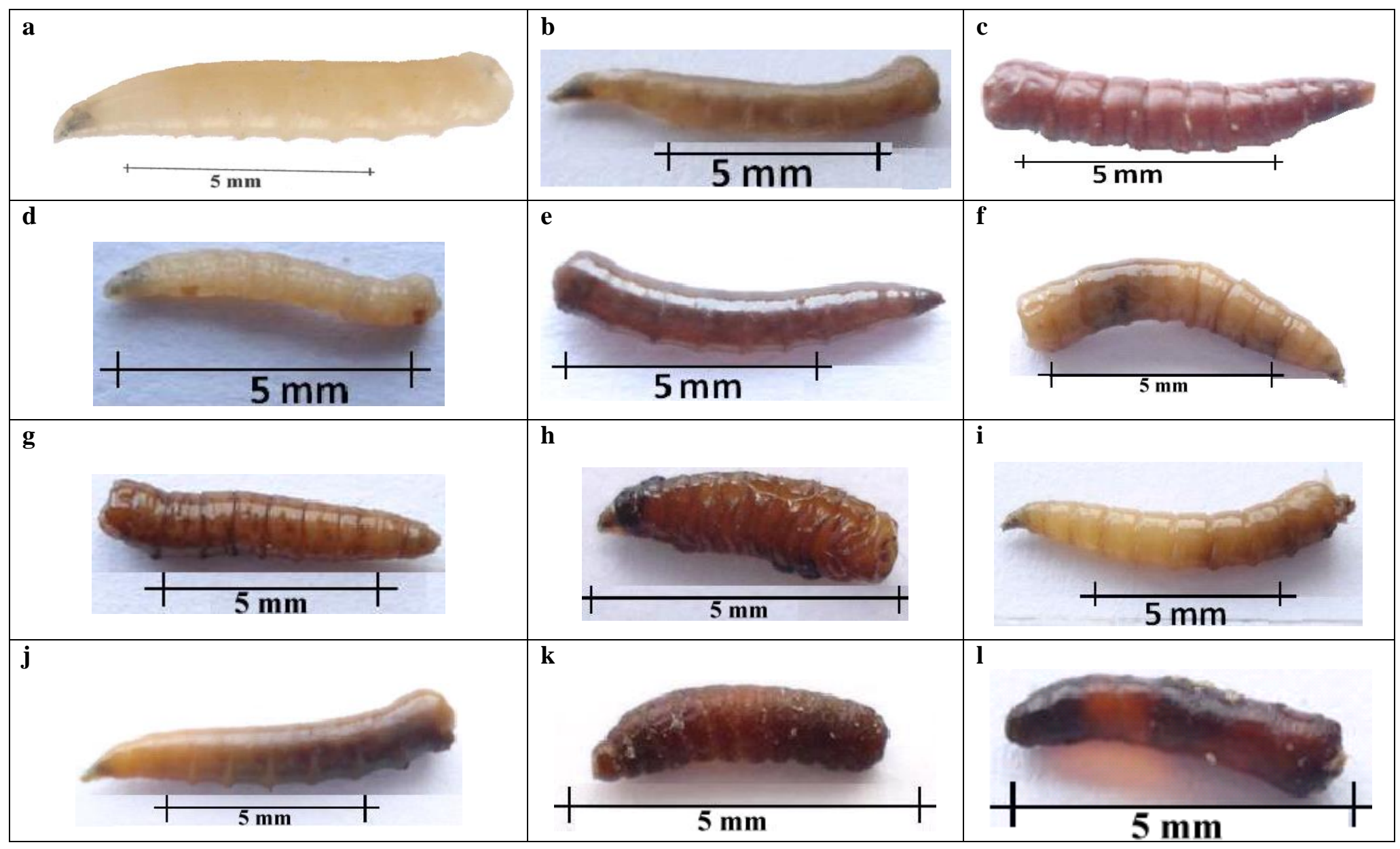

Plate 1: Normal and treated larvae of $M$. domestica: a, normal larva; b \& c, P. zonale treated; d \& e, C. rotundus treated; f-h, C. macrocarpa treated and i-1, A. nilotica treated. 


\section{Effect of some....}

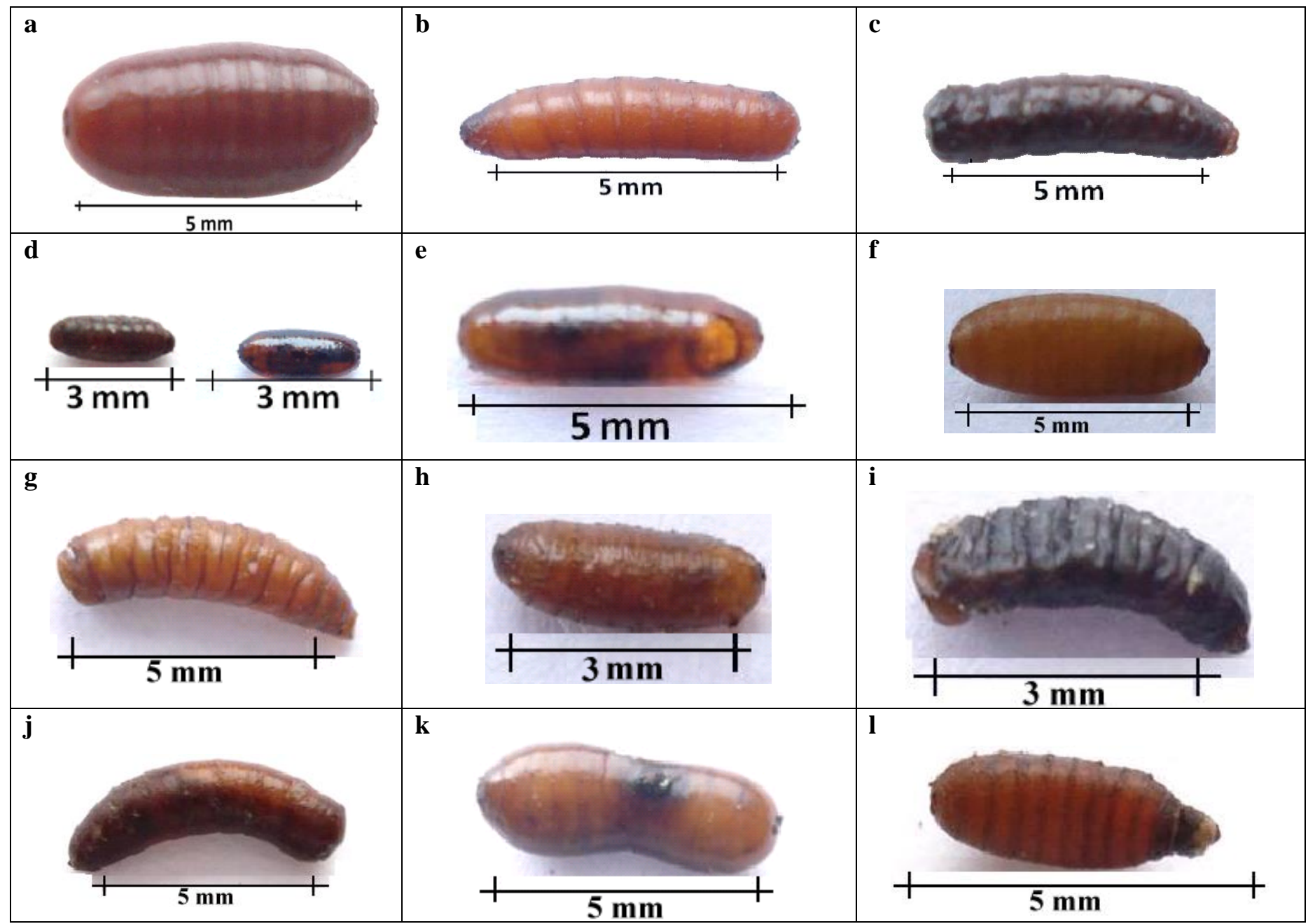

Plate 2: Normal and treated pupae of $M$. domestica: a, normal pupa; b, L. camara treated; c, $P$. zonale treated; d-f, C. rotundus treated; g-i, C. macrocarpa treated and $\mathrm{j}-1$, A. nilotica treated. 
Nabawy Elkattan... et al

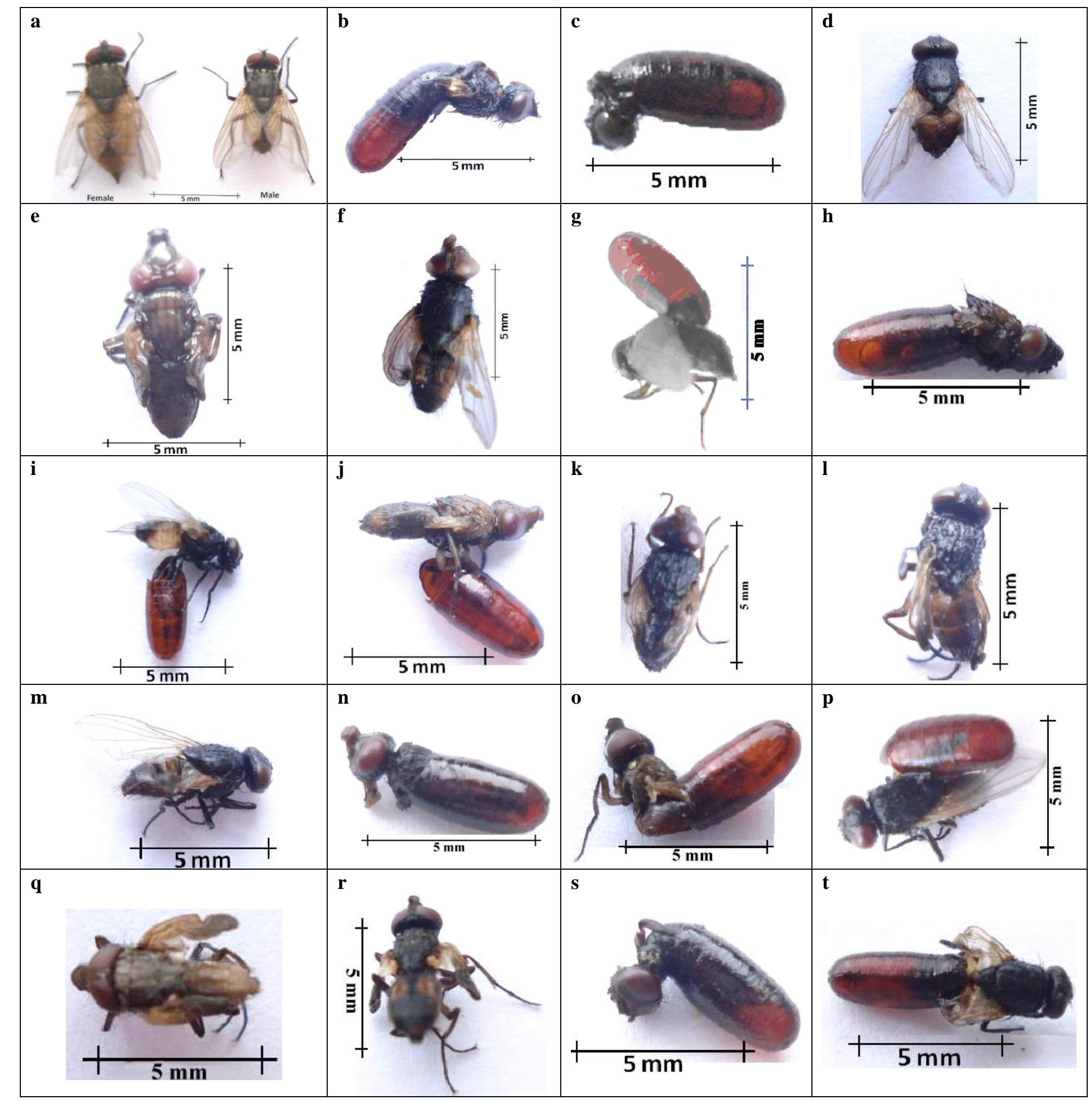

Plate 3: Normal and adults resulted from larvae treated with plant materials in $M$. domestica: a, normal adults; b-f, L. camara treated; g, P. zonale treated; h-m, C. rotundus treated; n-p, $C$. macrocarpa treated and q-t, A. nilotica treated. 


\section{Discussion}

In the present study, prolongation of the larval duration with tested plants was similar to that reported in $M$. domestica by Gad-Allah (1991) using Melia azedarach and Venca rosea, Ande (2001) using Peganum harmala, Acalypha. indica and Calotropis gigantic, Assar (2002 and 2003) using Lupinus termis, Calotropis procera and Atriplex inflate and Bakr et al. (2003) using Artemisia monosperma, Conyza dioscoridis, Clerodedron inerme, Clocasia antiqorum. Likewise, white and black mustard lengthened the duration of $2^{\text {nd }}$ larval instars of $M$. domestica (Abdel Kadder, 2005). Also, shortened larval period after A. nilotica treatment was in accordance with Shaalan et al. (2005) in Aedes aegypti larvae treated with Callitris glaucophylla. They stated that larvae observed to pupate faster as their environment increased in toxicity. This is clearly a self preservation mechanism since the pupal form is less susceptible to the environment.

The percent pupation was decreased as the concentration of plant powder increased. Similar observation was also reported, reduction of percentage of pupation by $91.57 \%$, after treatment of $3^{\text {rd }}$ larval instar of Synthesiomyia nudiseta with $\mathrm{LC}_{50}$ of $C$. macrocarpa oil (Khalaf et al., 2009). Similar effects of some botanical plant extracts have been reported on $M$. domestica by Abou El Ela et al. (1995); Ande (2001); Assar (2002 and 2003) and Bakr et al. (2003).

The decrease of pupal weight in the present study may be attributed to the decrease in total water content or decreased intensity of protein biosynthesis (Abdel Aal, 1996). Also, it may be due to the lack of proper sclerotization of the newly formed puparium, or evaporation of body fluids leading to decreased pupal weight. The effect of the tested plant powders on the mean pupal weight of pupae treated as larvae agrees with the results obtained on $M$. domestica by Kilani et al. (1991); Ande (2001); Assar (2003) and Bakr et al. (2003).
Prolongation in the pupal duration was observed in all tested concentration of all plant materials. Similar observation was also reported on $M$. domestica by Assar (2003) using A. inflate, and Bakr et al. (2003) using Artemisia monosperma, Conyza dioscoridis, Eichhornia crassipes, Clerodedron inerme, Clocasia antiqorum, and Farestia aegyptia. On the contrary, other studies reported that other plants reduced pupal duration Bakr et al. (2003) using Zygophyllum coccineum on $M$ domestica and Khater and Shalaby (2008) using Cyperus esculentus on $C$. pipiens

The decrease in the percentage of adult emergence of $M$. domestica due to treatment with the tested plant materials was similar to the data reported previous by these plants on other dipteran species.

The total mean number of males and females of blowfly, Chrysomya chloropyga emerging from larvae feeding diet containing $5 \%$ of $L$. camara powder, were significantly less than those of the control (Muse et al., 2003). High reduction in adult emergence was achieved by larval treatment with $C$. macrocarpa and $A$. officinarum volatile oils against Synthesiomyia nudiseta (Khalaf et al., 2009).

Disturbance in sex ratio observed after treatment with botanical materials towards more males than females was similar to the data obtained by Robert and Olson (1989) they found a change in the sex ratio towards more males in $C$. quinquefasciatus after sub-lethal exposure propoxur and resmethrin. This is not always the case, since Shaalan et al. (2005) found a change in the sex ratio towards more females in Aedes aegypti after treatment with $\mathrm{LC}_{25}$ of Callitris glaucophylla. The shortened adult longevity was also shown in M. domestica treated with plant extracts tested by GadAllah (1991) and Shoukry (1997). On the contrary, the longevity of adult $M$. domestica was not affected by A. inflate (Assar, 2003) and jojoba oil (Amer et al., 2004). 
The accumulation of the plant powders in different developmental stages of $M$. domestica might be expected to decrease the longevity of adult flies, as reported in S. littoralis after the treatment with Abrus precatorious extract (Dimetry and Abdallah, 1991).

The results obtained by the current study indicated that treatment of $M$. domestica larvae with all tested plant powders with all concentrations caused decrease in egg production. Some explanations were introduced by different authors revealing the possible reasons for the reduction of insect fecundity and as a result increasing sterility following the treatment with botanicals insecticides: (i) the weakened physical stage of the treated insects (Tripathi et al., 2003); (ii) mild suppressing effect exerted by the oil on the insect's mating-decisive factor influencing the subsequent number of eggs laid by the insect (Engelmann, 1970); (iii) partial sterilization of females and/or males, or the inability of the sperms to be transferred to the females during copulation (Ismail, 1980); (iv) reduction in the number of normal sperms produced by male insect (El-Meniawi et al., 1999); (v) a blockage in ovarian activity, as the tested botanical products may interfere with oogenesis which, in turn, results in a complete and irreversible sterility of insect female flies (Di Ilio et al., 1999; Khan $\boldsymbol{e t}$ al., 2007) and (vi) a delay or reduction of ova giving some opportunities not for retention but for possible egg re-sorption within ovaries. Also, that delay could be due, in part, to a lower metabolic rate (Taher and Cutkomp, 1983; Lucantoni et al., 2006).

Moreover, some extracts from C. rotundus prevented the sexual maturity of $S$. gregaria (Bakr et al., 2008). Also, Saxena et al. (1992) found that extract of L. camara induced oviposition deterrent effect. The extract also had conspicuous activity against the eggs of pulse beetle, Callosobruchus chinensis deposited on treated seeds, leading to a pronounced reduction in progeny. As discussed by Weathersbee III and Tang (2002), the disruption of reproductive capability could lead to substantial population decline over time. Furthermore, Dhar et al. (1996) revealed that exposure to neem extract suppressed rather than inhibited oviposition in mosquitoes. Disturbance in sex ratio observed after treatment with $A$. nilotica (ratio males : females was 2: 1) may be the reason for the low number of eggs deposited by females emerged from treated larvae as compared with females emerged from untreated larvae.

Reduction in the egg hatching percent by plant materials was similar to findings reported by many authors using different plant oils and extracts against $M$. domestica, in which the decrease of egg production accompanied with increasing sterility; among these are: Matricaria chamomilla and Clerodendron inerme (Shoukry, 1997) Melia azedarach extract (Radwan, 2000), extracts from leaves and flowers of Datura innoxia (Al-Zubaidi et al., 2002) and A. inflate (Assar, 2003).

The morphological aberrations induced by plant powders were concentration dependant, in almost cases, the higher concentration the more morphogenetic aberrations. Adamski et al. (2005) observed that the degree of malformation was directly proportional to the concentration of pesticides. Our results made also clear co- relation with the recent findings reported from Khalaf $\boldsymbol{e t}$ al. (2009) where the essential oil of $C$. macrocarpa had been reported to produced clear morphological abonrmalities in $S$. nudiseta. Some deformed larvae were pigmented and larval-pupal intermediate, the resultant some individuals showed C-shaped pupae, elongated pupae and balloon shaped pupae, most of the pupae failed to reach adults, however, some emerged adult have various degrees of morphological abnormalities. Topical application of the ethanolic extract from $C$. rotundus onto the penultimate instar nymphs of $S$. gregaria resulted in the formation of defected adults (Bakr et al., 2008). Similar abnormalities were reported by Hashem and Youssef (1991), they 
observed dark intersegmental pigments on the $3^{\text {rd }}$ larvae of $M$. domestica and fully formed pupa but with a constricted puparium after treatment the $1^{\text {st }}$ instar larvae with methanolic extraction of leaves and flowers of M. azedarach. Bakr et al. (2003) found larval pupal intermediate as a result of treatment of $M$. domestica larvae with $A$. monosperma, $C$. inerme and $C$. antiqorum. El-Domiaty et al. (2003) found shrinkage of the pupae and folding of the wing of adults as a result of treatment of $3^{\text {rd }}$ instar larvae of $M$. domestica with $P$. nigra volatile oil. Sripongpun (2008) observed small sized pupae $(1 \mathrm{~mm}$ wide $\times 3 \mathrm{~mm}$ long) after treated $M$. domestica larvae with the extract of Chinese star anise fruits, while the size of the control ones was $2 \mathrm{~mm}$ wide $\mathrm{x} 5 \mathrm{~mm}$ long. In addition, the number of small pupae developed to adults was less than that of normal one.

Sometimes highly melanized pupae (pupa with darkened puparium) were noticed as a result of treatment. These abnormalities are similar to the effect of IGR's against $M$. domestica as pointed out by Khalil $\boldsymbol{e t}$ al. (2010). This indicates that plant powders have also IGR effect.

As a result of treatments, cuticle melanization in patches were observable in $M$. domestica larvae. This phenomenon was observed previously with Shoukry (1996) who studied the histopathological effects of Chamomile and Jasmine oils on the house fly larvae. Ultrastructure of muscles of the treated larvae showed that those compounds induced disorganization of light and dark bands of the muscles. This may be the possible explanation for the melanized patches of cuticle or may be due to the inhibition in melanin synthesis (Gelbič and Němec, 2001). El Hadek (2002) stated that the malformation in prepupal stage, as it appeared as larval-pupal intermediate, may be due to the treated larvae were unable or failed to free themselves from their old cuticle.

In the present study, some of the pupae failed to reach adults. This result was observed previously (Jahan et al., 1990), as a number of adults failed to come out from the puparium. Similar results were obtained by Naqvi et al. (2007) using N-9 (extract from neem tree) against $M$. domestica. Ande (2001) stated that diet of housefly containing these plant materials no doubt contains desirable primary or secondary principles which may have developed from the interactions of the components of the diet. These principles elicit biological activities in respect of larval/pupal transformation and pupal eclosion hindrances.

Emerging of adults with malformed wings may be attributed to the failure of the wings to expand and flatten after adult emergence (Saxena et al., 1981). Aly et al. (2010) attributed the adult malformation of $S$. gregaria to the intervening of $F$. bruguieri extracts with the hormonally controlled program of morphogenesis. This may be due to the modification of the ecdysteroid titer, which in turn leads to changes in lysosomal enzyme activity causing overt morphological abnormalities (Josephrajkumar et al., 1999).

\section{Conclusion}

The results of the present biological studies suggest that the application of plant materials prevented normal development of the different developmental stages of $M$. domestica. Thus, L. camara, P. zonale, C. rotundus, C. macrocarpa and A. nilotica were nearly comparable with the insect growth regulators (IGR's) in its effects. All are able to reduce larval and pupal weights, adult emergence and the number of laid eggs, shorten adult life span and resulted in larval-pupal intermediates (Shaurub et al., 1998 and Naqvi et al., 2007). According to the current data, L. camara, $P$. zonale, C. rotundus, C. macrocarpa and A. nilotica powders are harmful to $M$. domestica, not only reducing longevity of adults but also decreasing their reproductive potential. In conclusion, $L$. camara, $P$. zonale, $C$. rotundus, $C$. macrocarpa and A. nilotica show effective IGR-like activities and exhibit great promise in suppressing populations of $M$. domestica. 


\section{References}

Abdel Kadder A H (2005). Toxicological and histopathological effects of some botanical extracts on the housefly Musca domestica L. (Muscidae: Diptera). Ph.D. Thesis, Fac. Sci., Zool. Dept., El- Minia Univ. Egypt.

Abdel-Aal A E (1996). Biological, histological and physiological effects of some insect growth regulators on the greasy cutworm, Agrotis ipsilon (Lepidoptera: Noctuidae). M.Sc. Thesis, Fac. of Sci., Cairo Univ. Egypt.

Abou El Ela R G, Helmy N M, El Monairy O M and Salah H (1995). Biological activity of an extract from Hyoscyamus muticus on Musca domestica (Diptera: Muscidae). Bull. Ent. Soc. Egypt. Econ. Ser., 22: 27- 35.

Adamski Z, Niewadzi $M$ and Ziemnicki $K$ (2005). Inheritance of chorionic malformations and insecticide resistance by Spodoptera exigua. J. Appl. Entomol., 129: 526-533.

Aly S A, El Ebiarie A S and Hamadah K S (2010). Effects of the wild plant, Fagonia bruguieri on the adult performance and phase transition of schistocerca gregaria (orthoptera: acrididae). Egypt. Acad. J. Biolog. Sci., 3 (2): 133-147.

Al-Zubaidi F S, Al Rubaie $\mathrm{H}$ M and Al Okaily L N (2002). The effects of terpenoid compounds extracted from Datura innoxia Mill on the biological performance of Musca domestica L. (Diptera: Muscidae). Proc. of the $2^{\text {nd }}$ Inter. Conf. on Biological Sciences, Fac. Sci. Tanta Univ.

Amer M S, Ghoneim K S, Al Dali A G, Bream A S and Hamadah K H (2004). Assessment of the bioactivity of Margosan-o and Jojoba against the house fly Musca domestica (Diptera: Muscidae). Al-Azhar Bull.Sci., 15(2): 9-24.

Ande A T (2001). Biological activities of some plant materials against the housefly Musca domestica. Nigerian Soci. for Experimental Biol. J., 1(4 ): 293-296.

Assar A A (2002). Biological and histopathological effects of the water pant extract of oshaar and termis on the larvae of the house fly, Musca domestica vicina Macq. (Diptera: Muscidae). J. Egypt. Ger. Soc. Zool., 38 (E): 33-51.

Assar A A (2003). Biological effects of the water extract of qataf Atriplex inflate (Chenopodiaceae) on the house fly, Musca domestica vicina Macq. (Diptera: Muscidae). J. Egypt. Ger. Soc. Zool., 41 (E): 15-28.

Bakr M E, Nassef N E, Assar A A, El-Sobky $M \quad M$ and Shams EI Din S A (2003). Biological and morphological effects of water extracts of some plants on the house fly, Musca domestica vicina Macq. (Diptera:
Muscidae). J. Egypt. Ger. Soc. Zool., 41 (E), 29-47.

Bakr R F A, Hussein M A, Hamouda L S, Hassan H A, Elsokary Z F (2008). Effect of some insecticidal agents on some biological aspects and protein patterns of desert locust, Schistocerca gregaria (Forskal). Egypt. Acad. Soc. Environ. Develop., 9(2): 29-42.

Crystal M M (1964). Insect fertility: inhibition by folic acid derivatives. Science, New Series, 144 (3616): 308 - 309.

Dhar R, Dawar H, Garg S, Basir S F and Talwar G P (1996). Effect of volatiles from neem and other natural products on gonotrophic cycle and oviposition of Anopheles stephensi and An. Culicifacies (Diptera: Culicidae). J. Med. Entomol., 33:195-201.

Di Ilio V, Cristofaro M, Marchini D, Nobili $P$ and Dallai $R$ (1999). Effects of a neem compound on the fecundity and longevity of Ceratitis capitata (Diptera: Tephritidae). J. Econ. Entomol., 92 (1): 76 - 82.

Dimetry $N Z$ and Abdallah E F (1991). Feeding deterrent effects of various extracts of the bead tree, Abrus precatorious seeds towards Spodoptera littoralis (Boisd.). Bull. Ent. Soc. Egypt, Econ. Ser., 17: 85 - 92.

Douglass $E$ S and Jesse C (2002). Integrated pest management for fly control in Maine dairy farms. Texas Agricultural Extension Service, 4. 6. pp.

Elbermaway S M, Elkattan N A I, Ahmed K $S$ and Abdel Gawad R M (2011). Screening for bioactive plant materials against house fly, Musca domestica L. (Diptera: Muscidae). Functional Plant Science and Biotechnology, 5(1): 45-51.

El Domiaty M M, El Shafae M M, Abdel Aal M M and Rashad E M (2003). Chemical composition and insecticidal activity of Populus nigra buds; growing in Egypt. J. Egypt. Acad. Soc. Environ. Develop., 3(2): 2140.

El Hadek M K M (2002). Phytochemical and toxilogical effect of plant extractives against Spodoptera littoralis (Biosd.) and Agrotis ipsilon (Hufnagel). M.Sc. Thesis, Econ. Entomol. \& Pestic. Dept., Fac. Agric., Cairo Univ.

El Meniawi F A, Hashem M, El Mesieri S M and Rawash I A (1999). Physiological effects of neem seed extracts on the reproductive activities of the cotton leafworm, Spodoptera littoralis Boisd. Alex. J. Agric. Res., 44(1): 79 $-96$.

Emerson P M, Lindsay S W, Walraven G E $L$, Faal H, Bogh C, Lowe $K$ and Bailey $R$ L (1999). Effect of fly control on trachoma and diarrhoea. Lancet 353: 1401-1403. 
Engelmann F (1970): The physiology of insect reproduction. Pergamon Press, New york.

Fletcher M G, Axtell R C and Stinner R E (1990). Longevity and fecundity of Musca domestica (Diptera: Muscidae) as a function of temperature. J. Med. Entomol., 27(5): 922926.

Gad Allah S Z (1991). The effect of some plant extracts on Musca domestica vicina. M. Sc. Thesis Fac. of sci., Cairo Univ. Egypt.

Gelbič I and Němec V (2001). Developmental changes caused by metyrapone and azadirachtin in Spodoptera littorallis (Boisd.) (Lep., Noctuidae) and Galleria mellonella (L.) (Lep., Pyralidae). J. Appl. Entomol., 125: 417422.

Ghoneim K S, Amer M S, Bream A S, Al Dali A G and Hamadah K S (2007). Effectiveness of Margosan-O and Jojoba on some reproductive aspects of the house fly, Musca domestica (Diptera: Muscidae). Inter. J. Agric. Biol. Friends Sci. Publishers, Faisalabad, Pakistan, 9 (2); 338-341.

Hashem H O and Youssef N S (1991). Developmental changes induced by methanolic extracts of leaves and fruits of Melia azedarach L. on the house fly, Musca domestica vicina Macq. J. Egypt Ger. Soc. Zool., 3 (E): 35-52.

Huang Q, Liu M, Feng J and Liu Y (2008). Effect of dietary benzoxadiazole on larval development, cuticle enzyme and antioxidant defense system in housefly (Musca domestica L.). Pesti. Biochem. and Physiol., 90: 119-125. Ismail I E (1980). Physiological studies on the effect of juvenile hormone analogues upon the cotton leafworm Spodoptera littoralis Boisd (Lep., Noctuidae) . Ph.D. Thesis, Cairo, Univ. Egypt.

Jahan M, Ahmad I and Naqvi S N H (1990). Toxic teratogenic effects of Juliflorine and Morgosan- $\mathrm{O}^{\mathrm{TM}}$ on the Musca domestica L., larvae. Proc. Pak. Congr. Zool. 10: 293299.

Jimenez Peydro R, Gimeno Martos C, Lopez Ferror J, Serrano Delgado C and Moreno Mari J (1995). Effects of the insect growth regulator, cyromazine, on the fecundity, fertility and offspring development of Mediterranean fruit fly, Ceratitis capitata Wied (Diptera: Tephritidae). J. Appl. Entomol., 119: 435-438.

Josephrajkumar A, Subrahmanyam B and Srinivasan (1999). Plumbagin and azadirachtin deplete haemolymph ecdysteroid levels and alter the activity profiles of two lysosomal enzymes in the fat body of Helicoverba armigera (Lepidoptera: Noctuidae). Eur. J. Entomol., 96: 347-353.
Kaufman P E, Scott J G and Rutz D A (2001). Monitoring insecticide resistance in house flies (Diptera: Muscidae) from New York dairies. Pest Management Science 57: 514-521.

Khalaf A A, Hussein K T and Shoukry K K (2009). Biocidal activity of two botanical volatile oils against the larvae of Synthesiomyia nudiseta (Wulp) (Diptera: Muscidae). Egypt. Acad. J. Biolog. Sci., 2 (1): 89-101.

Khalil M S, Assar A A, Abo El Mahasen M $M$ and Mahmoud S H (2010). Morphological effects of some insect growth regulators on Musca domestica, (Diptera, Muscidae). Egypt. Acad. J. biolog. Sci., 2 (2): 29- 36.

Khan M, Hossain $M A$ and Islam M S (2007). Effects of neem leaf dust and a commercial formulation of a neem compound on the longevity, fecundity and ovarian development of the melon fly, Bactocera cucurbitae (Coquillett) and the oriental fruit fly, Bactrocera dorsalis (Hendel) (Diptera: Tephritidae). Pak. J. Biol. Sci., 10: 3656-3661. Khater $H$ F and Shalaby A A (2008). Potential of biologically active plant oils to control mosquito larvae (Culex pipiens, Diptera: Culicidae) from an Egyptian locality. Rev. Inst. Med. trop. S. Paulo, 50(2):107-112.

Khazanie $R$ (1979). Elementary Statistics. Good Year Publishing Co., California, U.S.A.

Kilani I M, El Dib M A and El Fishawi A A (1991). The effect of aqueous neem, Azadirachta indica A.Juss, seed kernel extract on the house fly, Musca domestica L. Egypt J. Biological Pest Control, 1(1):121-128.

Kristensen $M$ and Jespersen J B (2003). Larvicide resistance in Musca domestica (Diptera: Muscidae) populations in Denmark and establishment of resistant laboratory Strains. J. Econ. Entomol., 96(4): 1300-1306.

Lucantoni L, Giusti F, Cristofaro $M$, Pasqualini L, Esposito F, Lupetti $P$ and Habluetzel A (2006). Effects of a neem extract on blood feeding, oviposition and oocyte ultrastructure in Anopheles stephensi Liston (Diptera: Culicidae). Tissue Cell 38: 361-371.

Lundgren L (1975). Natural plant chemicals acting as oviposition deterrent on cabbage butter flies, Pieris rapae (L.) and $P$. napi (L.). Zool. Ser., 4: 250-258.

Mian L S, Maag H and Tacal J V (2002). Isolation of Salmonella from muscoid flies at commercial animal establishments in San Bernardino County, California. J. Vector Ecol. 27: 82-85

Muse W A, Lajide $L$ and Adediri C O (2003). Effect of some nigerian plants on survival, oviposition, and emergence of adult blowfly, Chrysomya chloropyga (Wied.) 
(Diptera: Calliphoridae). J. Asia-Pacific Entomol., 6 (1): 69-75.

Naqvi $S$ N H, Tabassum R, Khan M F, Yasmin N, Nurulain S M and Burney A A (2007). Toxic, residual, and teratomorphic effect of a neem extract (N-9) in comparison to Coopex 25 WP (Permethrin + Bioallethrin) against Musca domestica L. (Holland strain). Turk. J. Zool., 31:127-130.

Pavela R (2008). Insecticidal properties of several essential oils on the house fly (Musca domestica L.). Phytotherapy Research 22 (2): 274-278.

Radwan M E H (2000). Effect of crude methanolic extracts of leaves and fruits of chinaberry tree Melia azedarach L. on the adult female housefly Musca domestica vicina Macq. M.Sc. Thesis, Fac. Sci. Alex. Univ.

Robert L L and Olson J K (1989). Effects of sublethal dosages of insecticides on Culex quinquefasciatus. J. Am. Mosq. Contr. Assoc. 5: 239-246.

Saxena R C, Dixit $O P$ and Harshan V (1992). Insecticidal action of Lantana camara against Callosobruchus chinensis (Coleoptera: Bruchidae). J. of Stored Prod. Res., 28 (4): 279-281.

Saxena R C, Waldbauer G P, Liquido N J and Puma B C (1981). Effect of neem oil on the leaf-folder, Cnaphlocrosis medinalis. Proc. $1^{\text {st }}$ Intn. Neem Conf. Rottach-Egern (1980): 189-203.

Shaalan E A S, Canyon D V, Younes M W F, Abdel Wahab $\mathbf{H}$ and Mansour $A \mathbf{H}$ (2005). Effects of sub-lethal concentrations of synthetic insecticides and Callitris glaucophylla extracts on the development of Aedes aegypti. J. Vector Ecol., 30(2): 295-298. Shaurub E H, Ahmed Z A and El Naggar $S$ E M (1998). Impacts of pyriproxyfen and extracts of Schinus terebinthifolius Raddi on development, reproduction and reproductive organs in Spodoptera littoralis (Boisd.) (Lepidoptera: Noctuidae). J. Egypt. Ger. Soc. Zool., 27 (E): 57 - 82.

Shono L Z and Scott J G (2004). Indoxacarb resistance in the house fly, Musca domestica. Pestic. Biochem. Physiol., 80: 106-112.

Shoukry I F I (1996). Morphogenic and histopathological effects induced by two natural volatile oils in the house fly, Musca domestica L. (Diptera: Muscidae). Proc. $1^{\text {st }}$ Conf. on the role of science in the development of Egypt. soc. and environ. Benha branch, Zag. Univ. 21 - 23 October, 112.

Shoukry I F I (1997). Delayed effects of the volatile oils of Matricaria chamomilla and Clerodendron inerme on fecundity, fertility and ovarian amino acids of the female Musca domestica L. Bull. Ent. Soc. Egypt, Econ. Ser.; 24: 52-60.

Sripongpun G (2008). Contact toxicity of the crude extract of Chinese star anise fruits to house fly larvae and their development. Songklanakarin J. Sci. Technol., 30 (5): 667672.

Taher M and Cutkomp K. (1983). Effect of sublethal doses of DDT and three other insecticides on Tribolium confusum. J. Stored Prod. Res., 19:43-50.

Tarelli G, Zerba E N and Alzogaray $\mathbf{R} A$ (2009). Toxicity to vapor exposure and topical application of essential oils and monoterpenes on Musca domestica (Diptera: Muscidae). J. Econ. Entomol., 102 (3): 1383-1388.

Toppozada A, Abd allah S and El Defrawi M E (1966). Chemosterilization of larvae and adult of the Egyptian cotton leafworm, Spodoptera littoralis by apholate-metapa and tepa. J. Econ. Entomol.; 59 : 1125-1128.

Tripathi A K, Prajapati V, Khanuja S P S and Kumar $S$ (2003). Effect of d-limonene on three stored-product beetles. J. Econ. Entomol.; 96(3): 990-995.

Wang-Jian, Li-ya and Lei Chaoliang (2005). The repellency and fumigant activity of Artemisia vulgaris essential oil to Musca domestica vicina. Chinese. Bull. Entomol., 42(1): 51-53.

Weathersbee III A A and Tang Y Q (2002). Effect of neem extract on feeding, growth, survival, and reproduction of Diaprepes abbreviatus (Coleoptera: Curculionidae). J. Econ. Entomol., 95: 661-667. 


\section{تأثير عدد من المواد النباتية على بعض النواحى البيولوجية للاببابة

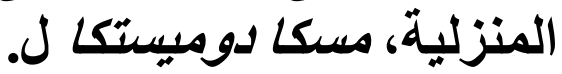

نبوى عبد الرحمن القطان، خلف الله صابر أحمد، سعدية محمد البرماوى، رباب مجدى عبد الجواد

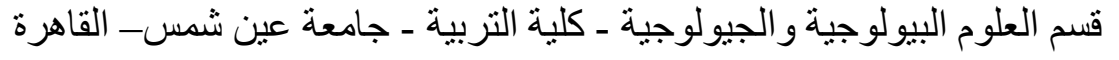

تم اختبار تاثير مطحون أوراق نباتات اللانتانا والبلارجونيوم و السرو الليمونى ومطحون نبات السعد

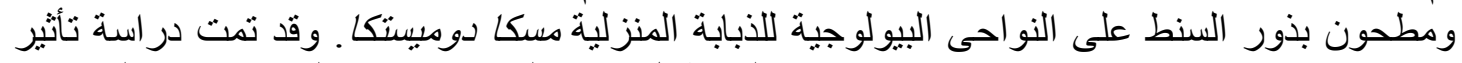
ثلاثة تركيزات مميتة (LC25, LC

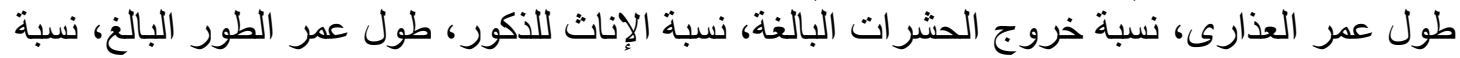

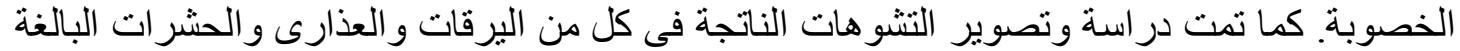

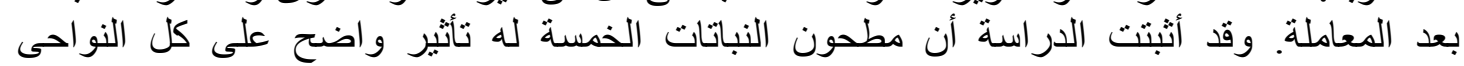

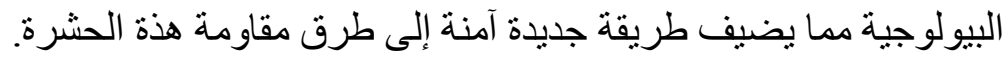

